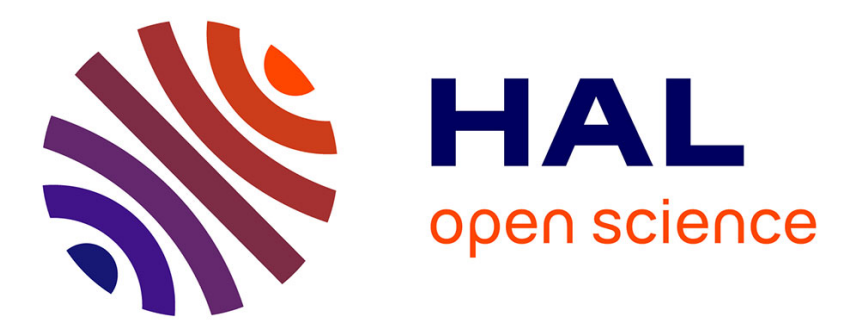

\title{
Marked increase in substance use among young people after L'Aquila earthquake
}

\author{
Rocco Pollice, Valeria Bianchini, Rita Roncone, Massimo Casacchia
}

\section{To cite this version:}

Rocco Pollice, Valeria Bianchini, Rita Roncone, Massimo Casacchia. Marked increase in substance use among young people after L'Aquila earthquake. European Child and Adolescent Psychiatry, 2011, 20 (8), pp.429-430. 10.1007/s00787-011-0192-2 . hal-00708548

\section{HAL Id: hal-00708548 \\ https://hal.science/hal-00708548}

Submitted on 15 Jun 2012

HAL is a multi-disciplinary open access archive for the deposit and dissemination of scientific research documents, whether they are published or not. The documents may come from teaching and research institutions in France or abroad, or from public or private research centers.
L'archive ouverte pluridisciplinaire HAL, est destinée au dépôt et à la diffusion de documents scientifiques de niveau recherche, publiés ou non, émanant des établissements d'enseignement et de recherche français ou étrangers, des laboratoires publics ou privés. 
Correspondence

Marked increase in substance use among young people after L'Aquila earthquake

Rocco Pollice, Valeria Bianchini, Rita Roncone, Massimo Casacchia

Department of Health Sciences, University of L'Aquila, 'San Salvatore' Hospital, L'Aquila, Italy

Corresponding author: Dr Rocco Pollice, Department of Health Sciences, Psychiatric Unit, University of L'Aquila, Via Vetoio, Loc. Coppito, I-67100, L'Aquila, Italy. Email: rocco.pollice@cc.univaq.it 
On December 3, 2010, a remarkable piece published in the Financial Times reported that "eighteen months after an earthquake struck the heart of Abruzzo, Italy, killing 309 people, the region's capital city, L'Aquila (town with a population of 72,000 and a health district of 103,788), is still a ghost town. Buildings and monuments have been secured and all the rubble removed, but the "red zone" in the 13th-century city centre is still a no-go area and its residents, relocated elsewhere, are starting to despair of ever returning". The 2009 L'Aquila earthquake (Richter magnitude 6.3) killing 309 residents, injuring over 2,500 , leaving 28,000 homeless and 66,000 displaced, caused destruction or serious damage to between 3,000 and 11,000 buildings (the $65 \%$ of building and homes).

Exposure to destruction and death caused by natural disasters has been shown to lead to psychological disorders and substance use as a byproduct of both the material and spiritual losses. ${ }^{1}$ This study provides data on how patterns of substance use changed among young people who survived the earthquake that struck L'Aquila on 6 April, 2009. A total of 1078 young subjects (mean age $21.4 \pm 5.6$ years) participated in a mental health survey conducted between March and December 2010. They represent the $8 \%$ of the population with age range of $16-30$ and the $1,5 \%$ of the general population. They were recruited in different settings: 323 of them self referrals at "S.M.I.L.E." (a psychiatric service for young people); 123 at SACS (a University Service of guidance and mentoring for students); the rest of them (632) were university and high school students, voluntarily enrolled to this survey.

All subjects screened that resulted positive to both the Patient Health Questionnaire (PHQ-9) and the Self-rating Anxiety State (SAS), after received diagnosis for psychiatric disorder. Consensus DSM-IV diagnoses were made by project psychiatrists according to the Structured Clinical Interview for DSM-IV (SCID I). Of them, 314 (29.1\%) had an ICD-10 diagnosis of anxiety disorders (43\%), mood disorders (34\%), post-traumatic stress 
disorder (16\%), and psychosis (7\%). There were 31 participants who had a personal or family history of physical trauma due to the earthquake. Increased substance use was assessed with one question per substance (alcohol, tobacco, cannabis) asking if the users had increased their use in the postearthquake compared with the preearthquake period. To this aim, a 4-point scale was used (none, less than before, equal to before, greater than before). The 12-item General Health Questionnaire (GHQ-12) was used for assessing perceived health. All participants provided their consent to participate in the study and the local ethical committee approved the study protocol.

In persons with an ICD-10 diagnosis of psychiatric disorders $(n=314)$, the use of alcohol, tobacco, and cannabis was reported to be increased in the postearthquake period by $179(57 \%), 128(41 \%)$ and $69(22 \%)$ subjects, respectively. Interestingly, none reported a reduced use of these substances following the disaster. In persons without an ICD-10 diagnosis of psychiatric disorders $(n=764)$, the use of alcohol, tobacco, and cannabis was reported to be increased in the postearthquake period by 374 (49\%), $289(38 \%)$, and 138 (18\%) subjects, respectively. None of the participants reported a reduced use of alcohol and nicotine, while $119(15.5 \%)$ indicated a reduced use of cannabis after the earthquake and these moreover scored significantly improvement on GHQ-12 than those with increased assumption $(p<0.001)$. Although our sample was not subjected to any specific investigation (i.e. the Post Traumatic Growth Inventory), in our clinical experience, especially those who reduced the use of cannabis, reported more intimate relationships, changed sense of priorities, greater appreciation of life and greater sense of personal strength.

In the entire sample, there was a moderate correlation between the increased use of alcohol and tobacco in female participants $(r=0.207)$. Similarly, the increased use of alcohol was significantly correlated with a higher use of tobacco $(r=0.340)$ and cannabis $(r=0.240)$ among males. Subjects with an ICD-10 diagnosis of psychiatric disorders 
scored significantly worse on GHQ-12 than those without $(p<0.001)$. Among these subjects, we found a statistically significant association between GHQ-12 scores and an increased use of nicotine $(p<0.04)$.

The results from this study clearly indicated a marked increase in substance abuse among young people who survived a catastrophic earthquake. We speculate that our participants reacted to emotional distress by turning to substance use in the absence of other, more adaptive coping mechanisms. Although we did not further explore the reasons behind the observed increase, our current findings confirm previous literature ${ }^{2-6}$ on a higher prevalence of substance use after traumatic experiences. As these findings may have important public health implications, we recommend to consider a routine assessment of increased substance use after natural disasters.

\section{References}

1. Vetter S, Rossegger A, Rossler W, Bisson Jl, Endrass J. Exposure to the tsunami disaster, PTSD symptoms and increased substance use - an Internet based survey of male and female residents of Switzerland. BMC Public Health 2008, 8: 92. 
2. Dew MA, Bromet EJ. Predictors of temporal patterns of psychiatric distress during 10 years following the nuclear accident at Three Mile Island. Soc Psychiatry Psychiatr Epidemiol 1993; 28: 49-55.

3. Green BL, Lindy JD, Grace MC, Gleser GC, Leonard AC, Korol M, Winget C. Buffalo Creek survivors in the second decade: stability of stress symptoms. Am J Orthopsychiatry 1990; 60: 43-54.

4. Marmar CR, Weiss DS, Metzler TJ, Delucchi KL, Best SR, Wentworth KA. Longitudinal course and predictors of continuing distress following critical incident exposure in emergency services personnel. J Nerv Ment Dis 1999; 187: 15-22.

5. Smith DW, Christiansen EH, Vincent R, Hann NE. Population effects of the bombing of Oklahoma City. J Okla State Med Assoc 1999; 92: 193-8.

6. Vlahov D, Galea S, Resnick H, Ahern J, Boscarino JA, Bucuvalas M, Gold J, Kilpatrick D. Increased use of cigarettes, alcohol, and marijuana among Manhattan, New York, residents after the September 11th terrorist attacks. Am J Epidemiol 2002; 155: 988-96.

The authors report no financial relationships with commercial interests.

We thank Drs. Annarita Tomassini, Roberta Ortenzi, Stefania Di Mauro, Maurizio Malavolta, Laura Verni, Ilaria Santini, Ida De Lauretis, and Natascia Giordani Paesani for their clinical assistance. 